\title{
JUJURAN ATAU MAHAR PADA MASYARAKAT SUKU BANJAR DI TINJAU DARI PERSPIKTIF PANDANGAN HUKUM ISLAM
}

'Sanawiah, Ikbal Reza Rismanto

'FAI Universitas Muhammadiyah Palangkaraya Kalimantan Tengah

\section{ABSTRAK}

Tujuan agama Islam Mensyari'atkan perkawinan adalah untuk memperoleh ketenangan hidup yang penuh cinta dan kasih sayang. Untuk memenuhi tujuan tersebut, maka harus memenuhi syarat dan rukunnya.Setiap daerah memiliki corak dan budaya yang dijunjung dan dipertahankan Jujuran atau Mahar merupakan salah satu syarat dalam tradisi perkawinan yang berlaku pada masyarakat suku Banjar, salah satunya di Kecamatan Pahandut Kota Palangka Raya Provinsi Kalimantan Tengah. Masyarakat Banjar melestarikan adat budaya yang dimiliki masing-masing tidak terkecuali pada tradisi yang dikenal dengan istilah Jujuran. Dalam bahasa hukum Islam disebut mahar ini turut menentukan berhasil atau tidaknya acara perkawinan nantinya.Pernah ditemui cerita batalnya perkawinan akibat pihak pria tidak bisa memenuhi permintaan besarnya Jujuran/mahar. Adapun yang menjadi pokok permasalahan ini adalah I) Apa dampak dari tradisi pemberian uang Jujuran terhadap prosesi pernikahan dan 2) Bagaimana pandangan Hukum Islam terhadap tradisi Jujuran Masyarakat suku Banjar di Kecamatan Pahandut Kota Palangka Raya. Penelitian ini menggunakan metode kualitatif deskriptif, dengan pengumpulan data, menggunakan teknik wawancara dan dokumentasi. Dari hasil Penelitian ditemukan suatu gambaran bahwa Jujuran dalam perkawinan hukum adat banjar di Kecamatan Pahandut Kota Palangka Raya Mempunyai nilai positif baik bagi pasangan suami istri yang baru menikah. Namun dilain pihak juga jujuran dapat menimbulkan hal yang negatif karena pihak wanita mengharapkan dan bahkan menentukan besarnya jujuran yang melebihi kemampuan calon suami. Demikian juga masalah Jujuran ini mempunyai perbedaan pendapat, ada yang mengatakan bahwa Jujuran ini sama dengan mahar dan ada pula yang mengatakan bahwa Jujuran ini berbeda dengan mahar. Sedangkan masalah mahar dalam hukum Islam pada dasarnya tidak ditetapkan. Pemberian yang dilakukan oleh suami yang berkaitan dengan akad nikah adalah mahar, jumlah besarnya Islam juga tidak menentukan, akan tetapi akan diserahkan pada kemampuan.

Kata Kunci: Jujuran, Masyarakat, Suku Banjar

\section{ABSTRACT}

The purpose of Islam dictated marriage was to get full of love and affection of peaceful life. To fulfil that purpose, so it must fulfill its requirement and pillar. Each region had style and culture which upheld and kept. Jujuran or Mahar was one of requirement of marriage tradition in Banjar tribe community, one of them in Pahandut district Palangka Raya Central Kalimantan.

Banjar community kept their cultural custom including Jujuran tradition. In language of Islamic law, this mahar could determine success or failure the wedding ceremony. There was story, failure of marriage because man could not fulfill request of amount jujuran/mahar. The main problems were I) What impact of giving jujuran money tradition on wedding procession and 2) How view of Islamic law on Jujuran tradition of Banjar tribe community in Pahandut district Palangka Raya.

This research used descriptive qualitative method, by data collection used interview and documentation techniques.

From research result found a description that Jujuran in marriage of Banjar custom law in Pahandut District Palangka Raya had positive value for new marriage couple of husband and wife. But on the other hand jujuran could make negative case because woman's side wanted and determined amount jujuran more candidate husband ability. This jujuran had different opinion, there one told that this jujuran same with mahar and there also one told that this jujuran different with mahar. While basically mahar in Islamic law was not determined. Giving from husband which related with marriage contract was mahar. Islam also was not determine the big amount but it would be matched with ability.

Key Words: Jujuran, Community, Banjar Tribe 


\section{A. PENDAHUluAN}

Allah SWT menciptakan makhluk hidup berpasang-pasangan, Allah memerintahkan agar umatnya melakukan perkawinan dengan syarat dan rukun yang telah ditetapkan. Perkawinan adalah sunatullah artinya perintah Allah dan Rasul-Nya tidak hanya semata-mata keinginan manusia, atau hawa nafsunya saja, karena seseorang yang telah berumahtangga berarti ia telah mengerjakan sebagian dari syari'at (aturan) Agama Islam. Allah mensyariatkan pernikahan dan dijadikan dasar yang kuat bagi kehidupan manusia karena adanya beberapa nilai yang tinggi dan beberapa tujuan yang baik bagi manusia, makhluk yang dimuliakan Allah SWT.Untuk mencapai kehidupan yang bahagia dan menjauhi ketimpangan dan penyimpangan, Allah telah membekali syariat dan hukumhukum Islam agar dilaksanakan manusia dengan baik. Pernikahan adalah sarana terpercaya dalam memelihara kontinuitas keturunan dan hubungan, menjadi sebab terjadinya ketenangan, cinta dan kasih sayang. Sedangkan menurut hukum Islam, Pernikahan adalah akad yang sangat kuat atau miitsaaqon ghaliidhan untuk menaati perintah Allah dan melaksanakannya merupakan ibadah.

Pernikahan merupakan salah satu ciri kekuasaan Allah SWT, seorang isteri diciptakan dari tulang rusuk suami.Hal ini agar setiap pasangan merasa tenteram dalam menjalankan kehidupan di dunia.Selain itu Allah SWT memberikan rasa kasih sayang kepada setiap orang yang menikah. Rasa kasih sayang inilah yang akan memberikan kebahagiaan bagi keluarga. Oleh karena itu, orang yang tidak menikah, baik laki-laki maupun perempuan, tidak akan merasakan nikmat sebagaimana yang dirasakan oleh orang yang menikah dalam aturan syariat Islam. Mereka tidak akan merasakan kebahagiaan berkeluarga, memiliki anak, dan lain sebagainya.

Pernikahan adalah sunnah karuniah yang apabila dilaksanakan akan mendapat pahala tetapi apabila tidak dilakukan tidak mendapatkan dosa tetapi dimakruhkan karena tidak mengikuti sunnah rosul. Menurut bahasa, nikah adalah menggabungkan, berkumpul dan menghimpun, setiap penggabungan antara dua hal disebut dengan nikah. Sedangkan definisi nikah menurut istilah adalah akad perkawinan yang sah.

Perkawinan merupakan sunnatullah yang umum dan berlaku pada semua makhluknya, baik pada manusia, hewan maupun tumbuhtumbuhan.la adalah suatu cara yang dipilih oleh Allah SWT., sebagai jalan bagi makhluknya untuk berkembang biak untuk melestarikan hidupnya.

Arti pernikahan menurut Undang-Undang Nomor I Tahun 1974 adalah ikatan lahir batin antara seorang pria dengan seorang wanita sebagai suami istri dengan tujuan membentuk keluarga (rumah tangga) yang bahagia dan kekal berdasarkan Ketuhanan Yang Maha Esa.

Allah SWT berfirman:

Artinya: "Dan di antara tanda-tanda kekuasaanNya ialah Dia menciptakan untukmu isteri-isteri dari jenismu sendiri, supaya kamu cenderung dan merasa tenteram kepadanya, dan dijadikanNya diantaramu rasa kasih dan sayang. Sesungguhnya pada yang demikian itu benarbenar terdapat tanda-tanda bagi kaum yang berfikir."

Keluarga merupakan gerbang kekuatan sebuah masyarakat, karena setiap individu dalam keluarga akan mengusung nilai moral mereka ke dalam sebuah masyarakat. Dengan pendidikan keluarga yang baik, akan muncul generasi baru yang mempunyai nilai moral tinggi. Moral inilah yang secara langsung ataupun tidak langsung akan membangun identitas sebuah masyarakat bahkan negara. Membangun keluarga berarti membangun sebuah peradaban, pendidikan kelslaman yang baik dalam keluarga akan menjadikan keluarga tersebut memiliki karakter Islam yang kuat. Segala sesuatu akan baik jika diawali dengan hal yang baik. Begitu pula dengan keluarga.

Keluarga akan menjadi keluarga yang baik jika dimulai dengan sebuah ikatan suci yang di dalamnya terdapat perjanjian yang kuat dalam bentuk pernikahan. Pernikahan harus didasari oleh niat. Niat yang benar akan mempermudah mewujudkan keluarga sakinah, mawaddah, 
warahmah Jika sudah demikian keluarga akan dihiasi oleh keberkahan yang datang dari Allah SWT. Membangun peradaban yang baik dan sehat bisa dimulai dengan membangun keluarga yang sehat secara Islam, sekecil apapun kontribusi yang dilakukan akan selalu bermanfaat dalam membangun peradaban yang baik. Allah SWT tidak akan menurunkan pertolongan-Nya kecuali manusia tersebut mengubah diri mereka ke arah yang lebih baik. Sebuah keluarga harus dilandasi oleh pernikahan dengan niat ibadah kepada Allah SWT, proses yang benar dalam melangsungkan perkawinan akan berpengaruh kepada jalan kehidupan keluarga itu sendiri.

Berbicara tentang perkawinan, tidak terlepas dari apa yang disebut dengan maskawin atau mahar karena hal itu merupakan sesuatu yang menjadi hak seorang isteri sebagai kompensasi dari sebuah perkawinan dengan seorang laki-laki. Dalam pendapatlain dikatakan bahwa mahar yang diberikan oleh seorang lakilaki bukan merupakan pemberian, melainkan sebagai kompensasi atas kenikmatan yang diperolehnya. Mahar adalah harta yang dikeluarkan atau manfaat yang dikeluarkan untuk akad nikah atau kewajiban untuk melakukan akad nikah dan apa-apa yang memiliki kaitan dengannya.

Dalam hukum perkawinan Islam mahar merupakan kewajiban yang harus dibayar oleh seorang pengantin laki-laki kepada pengantin perempuan sesuai dengan kemampuannya. Mahar atau Mas kawin dalam Bahasa Arab adalah Shadaq diambil dari kata Ash-shidqiuntuk menunjukkan betapa kuatnya cinta (keinginan) sang suami terhadap isteri. Asalnya isim masdar dari kata Ashadaqa, masdarnya Ishdaq diambil dari kata Shidqin (benar).Dinamakan Shadaq memberikan arti benar-benar cinta nikah dan inilah yang pokok dalam kewajiban mahar atau maskawin.

Dalam Kompilasi Hukum Islam Pasal 30, disebutkan bahwa calon mempelai pria wajib membayar mahar/mas kawin kepada calon mempelai wanita yang jumlahnya, bentuk dan jenisnya disepakati oleh kedua belah pihak, sedangkan pada Pasal 3I, disebutkan pula bahwa penentuan mahar berdasarkan asas kesederhanaan dan kemudahan yang dianjurkan oleh ajaran Islam Pembayaran mahar adalah wajib menurut al-Qur'an, Allah SWT berfirman:
Artinya: "Berikanlah maskawin (mahar) kepada wanita (yang kamu nikahi) sebagai pemberian dengan penuh kerelaan, kemudian jika mereka menyerahkan kepada kamu sebagian dari maskawin itu dengan senang hati, maka makanlah (ambillah) pemberian itu (sebagai makanan) yang sedap lagi baik akibatnya."

Ayat ini dihadapkan kepada laki-laki yang hendak melangsungkan perkawinan supaya dia memberikan kepada perempuan yang dikawininya itu maharnya dengan jumlah yang ditentukan.Pemberian tersebut muncul dari hati yang tulus ikhlas, dengan tidak ada maksud pergantian apapun. Pemberian mahar merupakan pemberian pertama seorang calon suami kepada calon isterinya yang dilakukan pada waktu sebelum akad nikah. Dikatakan yang pertama karena sesudah itu akan timbul beberapa kewajiban materil yang harus dilaksanakan oleh suami selama masa perkawinan untuk kelangsungan perkawinan itu. Dengan pemberian mahar itu seorang suami dipersiapkan dan dibiasakan untuk menghadapi kewajiban materiil berikutnya, sebagaimana dalam Kompilasi Hukum Islam Pasal 33 yang berbunyi:

a. Penyerahan mahar dilakukan dengan tunai

b. Apabila calon mempelai pria menyetujui, penyerahan mahar boleh ditangguhkan baik untuk keseluruhannya atau untuk sebagian. mahar yang belum ditunaikan menjadi hutang bagi calon mempelai pria.

Salah satu dari usaha Islam ialah memperhatikan dan menghargai wanita, yaitu memberinya hak untuk memegang urusannya.Di zaman jahiliyah hak perempuan itu dihilangkan dan disia-siakan sehingga wali dengan semena-mena dapat menggunakan hartanya, dan tidak memberikan kesempatan untuk mengurus hartanya dan menggunakannya, kemudian Islam datang menghilangkan belenggu ini, kepadanya diberi hak mahar.

Nabi Muhammad SAW, menghendaki mahar itu dalam bentuk yang wajar (sederhana). Pemberian mahar yang wajar itu akan tergantung pada kedudukan seseorang dalam kehidupannya, status sosial pihak-pihak yang menikah itu, dan dapat berbeda dari satu tempat dengan tempat yang lain, dari satu masa ke masa yang lain, dari satu negeri dengan 
negeri yang lain. Ditinjau dari perkataan seharihari mahar sama dengan maskawin, akan tetapi dalam masyarakat adat Indonesia, adat istiadat yang berlaku disuatu daerah di Negara kita, mahar (itu) tidak sama dengan maskawin yang biasa diberikan oleh pihak pria kepada pihak wanita. Menurut Hukum Adat, perkawinan yang berlaku di beberapa daerah di Indonesia maskawin mempunyai fungsi sendiri yakni mengembalikan keseimbangan magis dalam keluarga pihak perempuan karena wanita yang kawin itu akan pindah atau keluar dari lingkungan keluarganya semula.

Dalam hubungan adat istiadat tersebut dikenal dengan adatperkawinan suku Banjar yang merupakan tradisi pada masyarakat yang berdiam di pulau Kalimantan, yang menurut asal usul sejarahnya adalah disebut sebagai suku Dayak, akan tetapi karena memeluk agama Islam maka sekarang ini disebut sebagai suku Banjar. Suku Banjar adalah pemeluk agama Islam yang terbanyak di pulau Kalimantan, atau bisa juga disebut sebagai suku/orang Melayu karena enggan disebut sebagai orang Dayak yang identik dengan suku/orang non Muslim yang juga menjadi penduduk pulau Kalimantan.

Oleh karena itu tidak berlebihan kiranya suku Banjar sebagai pemeluk Islam yang taat memadukan dan menerapkan adat budaya dalam masyarakatnya ke dalam tradisi Jujuran yang merupakan bagian dari adat perkawinan suku Banjar yang banyak diberlakukan di wilayah Nusantara, salah satunya yaitu di Kecamatan Pahandut Kota Palangka Raya, memang penduduk di Kecamatan Pahandut Kota Palangka Raya terdiri dari berbagai suku, agama dan budaya, dari berbagai suku yang ada selain Suku Banjar adalah Dayak dan Jawa dll. Ketiga suku ini sangatlah menghormati dan melestarikan adat budaya yang dimiliki masingmasing tidak terkecuali pada tradisi yang dikenal dengan istilah Jujuran, yang termasuk dalam rangkaian adat perkawinan suku Banjar.

Jujuran adalah suatu pemberian dari pihak laki-laki kepada pihak wanita yang diberikan atas dasar kesepakatan bersama (pihak orangtua), disini uang Jujuran dibedakan dengan mahar.Jujuran dalam adat perkawinan Banjar adalah salah satu syarat yang harus dipenuhi oleh calon pengantin pria.Biasanya Jujuranini berbentuk uang tunai.Zaman dahulu Jujuranberjumlah empat rupiah sebagai syarat sah nikah mengikuti agama Islam. Namun seiring berkembangnya zaman jumlah Jujuran ini mengalami perubahan, saat ini mahalnya Jujuran bagi seorang gadis ditentukan oleh berbagai faktor, antara lain:

I. Status sosial orangtua si gadis, umpamanya orangtua si gadis adalah orang terpandang,

2. Kecantikan si gadis.

3. Tingkat pendidikan si gadis.

4. Pekerjaan.

5. Keinginan orangtua si gadis sebagai biaya perkawinan dan bekal hidup bagi kedua mempelai.

Dalam kebiasaan masyarakat suku Banjar yang berada di Kecamatan Pahandut Kota Palangka Raya, Jujuranini turut menentukan berhasil atau tidaknya acara perkawinan nantinya.Pernah ditemui cerita batalnya perkawinan akibat pihak pria tidak bisa memenuhi permintaan besarnya Jujuran.

Pada masyarakat umum jumlah Jujuran bisa juga diambil patokan dari besarnya Jujurankebanyakan orang di daerah tersebut. Melekatnya tradisi Jujuranpada masyarakat adat suku Banjar yang tinggal di Kecamatan Pahandut Kota Palangka Raya ini setidaknya memantik dampak-dampak sosial diantaranya, status sosial kedudukan pria suku Banjar dalam tradisi Jujuranadalah pria memiliki kedudukan yang tinggi karena pria yang memberikan Jujurankepada wanita, namun ada juga pandangan bahwa kedudukan pria dalam tradisi Jujuranmerupakan pihak yang ditekan oleh wanita karena yang menentukan besarnya jumlah Jujuran yang diminta adalah pihak wanita, munculnya perasaan cemas dan takut karena khawatir jumlah Jujuranyang diminta tidak dapat dipenuhi oleh pihak pria, selain itu dampak sosial yang diterima pria suku Banjar, setelah melaksanakan tradisi Jujuran adalah penilaian positif yang berupa pujian atau penilaian negatif yang berupa sindiran yang datang dari masyarakat, sedangkan dampak psikologis 
setelah melaksanakan tradisi Jujuran adalah perasaan senang karena terhindar dari penilaian negatif dari masyarakat, serta adanya perasaan bangga karena dengan melaksanakan tradisi Jujuran menaikkan harga diri di mata masyarakat.

Dampak sosial di atas, setidaknya akan membuat calon pengantin pria ini merasa tertahan untuk menikah, langkah mereka terasa berat, hati mereka ragu-ragu dan nyali mereka kecil untuk membangun rumah tangga. Padahal agama Islam menganjurkan memberi semangat untuk memperoleh kebolehan untuk menikah, tujuannya agar keduanya (pria dan wanita) memperoleh kehalalan, yang mana itu semua tidak akan sempurna diperoleh kecuali jika perantara menuju pernikahan telah dimudahkan jalannya. Adapun ukuran kemudahannya adalah ketika bagi seorang yang fakir mampu menyerahkan hartanya kepada wanita tersebut. Adapun yang menjadi pokok permasalahan ini adalah : Apa dampak dari tradisi pemberian uang Jujuran terhadap prosesi pernikahan?

Bagaimana pandangan Hukum Islam terhadap tradisi Jujuran Masyarakat suku Banjar di Kecamatan Pahandut Kota Palangka Raya.

\section{Metode Penelitian}

Penelitian ini menggunakan metode kualitatif deskriptif, dengan pengumpulan data, menggunakan teknik wawancara dan dokumentasi.

\section{Pembahasan}

\section{Pengertian Jujuran}

Jujuran berasal dari kata "jujur" yang dalam Kamus Besar Bahasa Indonesia berarti uang yang diberikan oleh calon pengantin lakilaki kepada calon pengantin perempuan. Jujuranadalah suatu pemberian dari pihak calon mempelai pria kepada pihak calon mempelai wanita baik berupa uang maupun berupa benda. Jadi istilah Jujuransama dengan istilah mas kawin atau mahar. Menurut Wikipedia bahasa Banjarjujuranadalah "harta yang diberikan oleh pihak mempelai laki-laki (atau keluarganya) kepada mempelai perempuan (atau keluarga dari mempelai perempuan pada saat pernikahan." Menurut Alfani Daud Jujuranmerupakan "besarnya maskawin yang harus diserahkan pihak jejaka kepada pihak gadis." Jujuranmerupakan pemberian dari pihak laki-laki kepada pihak perempuan untuk tujuan pernikahan. Merupakan adat sukuBanjar, jumlahnya ditentukan oleh pihak perempuan , tidak termasuk mahar atau seserahan. Berdasarkan definisi diatas penulis menyimpulkan bahwa Jujuranmerupakan pemberian calon mempelai laki-laki kepada calon mempelai perempuan berupa uang yang harus diberikan sebagai syarat untuk melaksanakan perkawinan.

\section{Besarnya Jujuran}

Besaran nilai Jujuran tergantung oleh beberapa hal seperti latar belakang wanita, semakin terpandang dan terhormat keluarga wanita tersebut maka semakin tinggi nilai Jujuran-nya. Selain itu Jujuranjuga ditentukan oleh kecantikan, semakin cantik paras wanita tersebut maka semakin tinggi pula nilai Jujurannya. Saat ini faktor yang mempengaruhi nilai Jujuranadalah tingkat pendidikan si wanita, saat ini banyak wanita suku Banjar yang mengenyam pendidikan cukup tinggi dan telah memiliki karir.Status dan karir wanita inipun menentukan faktor yang mempengaruhi nilaijujuran.Semakin tinggi pendidikan dan karir wanita yang akan dinikahi maka nilai Jujuran makin tinggi pula. BentukJujuranatau mahar biasanya berupa uang atau barang berharga lainnyadan sering dilengkapi dengan seperangkat alat sholat dan kitab suci AIQur'an.

\section{Dasar hukum Jujuran}

Dalam hukum yang berlaku tentang Jujurandalam perkawinan adalah berdasarkan kepada adat atau kebiasaan pada masyarakat suku Banjar, ini terjadi sejak zaman orangtua dulu, ketika Islam masuk di daerah Kalimantan Selatan, namun Islam tidak ada menjelaskan tentang kedudukan Jujuran, tetapi Islam memiliki kaidah hukum yang dapat menjadi pegangan, yaitu mengakui adat suatu masyarakat yang dipandang baik secara habitat dan berlaku umum dalam masyarakat tertentu.

Hal ini sesuai dengan kaidah hukum Islam yang menyatakan tentang kebolehan menjalankan hukum adat atau kebiasaan yang sudah berlaku sejak dulu, dan ini bisa dijadikan sebagai sandaran hukum. Kaidah itu adalah sebagai berikut:

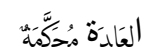


Artinya:"Adat kebiasaan dapat ditetapkan sebagai hukum."

Dasar ini didukung oleh sumber hukum yaitu Al-Qur'an, sebagai mana firman Allah:

Artinya: "Jadilah Engkau Pemaaf dan suruhlah orang mengerjakan yang ma'ruf, serta berpalinglah dari pada orang-orang yang bodoh."

Menurut Usman dalam bukunya KidahKaidah Ushuliyah dan Fiqhiyah, bahwa adat itu dapat diterima apabila memenuhi persyaratanpersyaratan berikut ini:

a. Perbuatan yang dilakukan logis dan relevan dengan akal sehat. Syarat ini menunjukkan bahwa adat tersebut tidak mungkin berkenaan dengan perbuatan maksiat.

b. Perbuatan dan perkataan yang dilakukan selalu berulang-ulang atau sudah mendarah daging tumbuh dan berkembang pada masyarakakat tersebut.

c. Tidak bertentangan dengan Alqur'an dan Al-hadits.

d. Tidak mendatangkan dengan kemudharatan serta sejalan dengan akal dan jiwayang sejahtera.

\section{Rukun dan syarat pernikahan}

Rukun yaitu sesuatu yang mesti ada yang menentukan sah atau tidaknya pekerjaan (ibadah), dan sesuatu itu termasuk dalam rangkaian pekerjaan itu seperti membasuh muka untuk wudhu dan takbiratul ihram untuk sholat atau menurut Hukum Islam calon pengantin laki-laki/perempuan dalam perkawinan. Syarat adalah sesuatu yang mesti ada yang menentukan sah atau tidaknya suatu pekerjaan (ibadah), tetapi sesuatu itu tidak termasuk dalam rangkaian pekerjaan itu, seperti menutup aurat untuk sholat, menurut Hukum Islam calon pengantin laki-laki/perempuan itu harus beragama Islam.Untuk sahnya akad pernikahan disyaratkan empat perkara yaitu mahar, walimah, saksi dan wali. Pernikahan tidak dapat terjadi kecuali rukun-rukun dan syarat-syaratnya telah dipenuhi, dan telah maklum bersama bahwa rukun adalah sesuatu yang terwujudnya tergantung padanya karena sesuatu itu merupakan bagian dasar dan termasuk dalam hakikatnya. Sedangkan syarat adalah sesuatu yang harus ada dan harus terjadi agar akad nikah menjadi sah, akan tetapi ia bukan merupakan bagian darinya dan tidak termasuk dalam Hakikatnya.

Pada garis besarnya syarat sah pernikahan itu ada dua yaitu:

I. Laki-laki dan perempuannya sah untuk dinikahi, artinya kedua calon pengantin adalah orang yang bukan haram dinikahi, baik karena haram untuk sementara atau selamanya.

2. Akad nikahnya dihadiri oleh para saksi.

Menurut pendapat Imam Syafi'i bahwa rukun nikah ada lima macam:

I. Calon pengantin laki-laki.

2. Calon pengantin perempuan.

3. Wali.

4. Dua orang saksi.

5. Sighat akad nikah.

Dalam Kompilasi Hukum Islam, pada Bab 5 bagian kesatu yaitu rukun, dalam Pasal I4 dinyatakan bahwa untuk melaksanakan perkawinan itu harus ada:
a. Calon suami
b. Calon istri
c. Wali nikah
d. Dua orang saksi.

Dari data-data hasil wawancara yang diperoleh dan diuraikan tersebut di atas, maka Penulis dapat mengambil analisis tentang pandangan dari eman subyek. Pendapat responden mengenai pengertian Jujuran, sebab penentuan Jujuran, dasar dalam penentuan Jujuran, nominal uang Jujuran, dampak uang Jujuran tidak diberikan, dampak jika calon pengantin laki-laki tidak menyanggupi membayar mengenai jumlah uang Jujuran yang diminta dan pandangan hukum Islam terhadap cara yang dilakukan kedua belah pihak dalam menyelesaikan problematika penentuan Jujuran, maka dapat diberikan analisanya tersebut dibawah ini. 
Sebagian besar responden menyatakan bahwa, Jujuran sama pengertiannya dengan mahar atau maskawin. Sedangkan yang berbeda pendapat hanya dua orang yang menyatakan bahwa Jujuran itu tidak sama dengan mahar, yang pertama memberikan kebebasan berpendapat bahwa Jujuran itu sama dengan duit atau uang mufakat, yang kedua bahwa Jujuran tidak sama dengan mahar karena mengandung unsur tawar menawar menurut adat Banjar.

Ada juga yang memberikan pengertian bahwa Jujuran sama dengan pemberian, maksudnya adalah pemberian uang dari calon pengantin laki-laki kepada calon pengantin perempuan dari hasil mufakat kedua belah pihak yang nominal sebelumnya telah diminta terlebih dahulu oleh pihak wali perempuan.

Jika memang Jujuran itu merupakan pemberian dari hasil kemufakatan maka hukum Islam membolehkannya, dasarnya adalah AlQur'an surah Annisa ayat 4 :

Artinya: "Berikanlah maskawin (mahar) kepada wanita (yang kamu nikahi) sebagai pemberian dengan penuh kerelaan, kemudian jika mereka menyerahkan kepada kamu sebagian dari maskawin itu dengan senang hati, Maka makanlah (ambillah) pemberian itu (sebagai makanan) yang sedap lagi baik akibatnya."

Pemberian itu ialah maskawin yang besar kecilnya ditetapkan atas persetujuan kedua pihak, karena pemberian itu harus dilakukan dengan ikhlas.Namun jika permintaan wali dari pihak perempuan meminta uang Jujuran terlalu tinggi atau terlalu besar nominalnya, Maka hukum Islam tidak membenarkan hal tersebut, Sekalipun fuqaha' sepakat bahwa tidak ada batas maksimal dalam mahar, tetapi seyogianya tidak berlebihan, khususnya di era sekarang. Hadits yang diriwayatkan dari Rasulallah SAW bersabda:

Artinya: "Wanita yang sedikit maharnya lebih banyak berkahnya."

$$
\text { حَرْرُ الصَّدَاقِ آَسَرْرُ هُنَّ }
$$

Artinya: "Sebaik-baik mahar adalah yang paling mudah."

Mahar diberikan kepada para isteri sebagai pemberian wajib, bukan pembelian atau ganti rugi.jika isteri setelah menerima maharnya tanpa paksaan lalu memberikan maharnya sebagian bukan karena malu, takut, atau terkicuh, maka boleh diterima.Hal tersebut tidak disalahkan atau dianggap dosa.Mahar menjadikan hati seorang isteri senang dan ridha menerima kekuasaan suaminya kepada dirinya, disamping itu mahar juga memiliki andil untuk memperkuat hubungan dan menumbuhkan tali kasih sayang dan cinta mencintai.

Setelah melihat pendapat responden pada tabel 2 yang berisi pendapat responden tentang sebab penentuan Jujuran,responden I (satu), 2 (dua), 3(tiga) dan 6 (enam) berpendapat sama yaitu harus ada mufakat kedua belah pihak. Sedangkan 2 (dua) responden berpendapat berbeda yaitu responden 5 (lima) menyatakan wajib karena sebelumnya responden tersebut telah menyatakan bahwa Jujuran itu sama dengan maskawin atau mahar sesuai dengan Qs. An-nisa ayat 4. Responden 4 (empat) berpendapat sebab penentuan Jujuran itu adalah untuk rencana resepsi pernikahan yang diberikan oleh calon suami, padahal jika jujuran itu merupakan suatu maskawin atau mahar maka itu bertentangan karena mahar atau maskawin itu diberikan ketika akad pernikahan yang langsung diberikan oleh pengantin laki-laki kepada pengantin perempuan karena mahar tersebut merupakan salah satu dari hak yang diberikan oleh suami kepada istri, dengan lapadznya misal sebagai berikut "Saya nikah dan kawinkan engkau dengan saudari pulanah binti pulang dengan mahar/maskawin Rp. 100.000 dan seperangkat alat sholat dibayar tunai." Kemuadian calon pengantin laki-laki menjawab."Saya terima nikahnya pulanah binti pulan dengan rmahar/maskawin tersebut tunai."

Setelah melihat pendapat responden pada tabel 3 tentang dasar dalam penentuan Jujuran 2 (dua) responden menyatakan sama yaitu suka sama suka dan 4 (empat) lainnya menyatakan berbeda ada yang menyatakan dari kemampuan laki-laki, tergantung mufakat, dan ada pula yang mengatakan mahar itu sudah ditentukan dari KUA. Menurut analisis Penulis jika Jujuran itu sama dengan maskawin maka Jujuran itu tidak sama dengan maskawin atau mahar dalam pandangan hukum Islam.

Pertama, yang paling berhak menentukan nilainya adalah wali pengantin wanita. Jika maharnya nilainya di bawah umumnya nilai mahar yang ada di masyarakat (mahar mitsl) karena urusan mahar, urusan pengantin wanita, sehingga dia tidak boleh 
menentukan sendiri. Dalam al-Mudawanah kitab fiqh Malikiyah dinyatakan, bahwa :

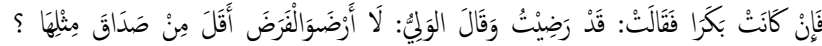

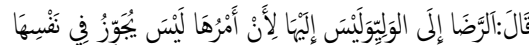

Artinya: "Jika dia gadis, dan mengatakan, "Saya setuju." Sementara wali mengatakan tidak setuju, dan mahar kurang dari nilai mahar mitsl, menurut Ibnul Qosim, persetujuan kembali kepada wali, bukan ke si pengantin.Karena urusan dirinya, tidak boleh dikembalikan ke pribadinya."

Namun jika mahar itu senilai mahar mitsl, maka persetujuan kembali kepada pihak wanita.

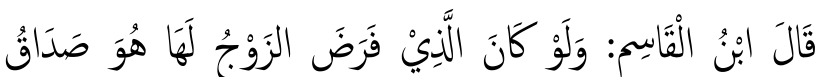

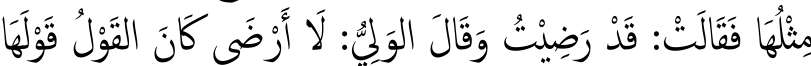

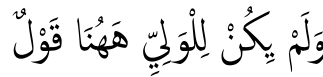

Artinya : "Ibnul Qosim mengatakan, “Jika yang mahar yang disediakan suami untuk si istri adalah "mahar mitsl, lalu istri menyatakan setuju. Sementara wali menyatakan tidak setuju, maka persetujuan yang dianggap adalah persetujuan istri. Dalam hal ini, wali tidak punya hak pendapat."

Kedua, yang paling berhak menentukan nilai mahar adalah pengantin wanita. Sementara wali sama sekali tidak berhak menggugatnya. Meskipun nilainya di bawah mahar mitsl.Syahnun ulama Malikiyah mengatakan, bahwa:

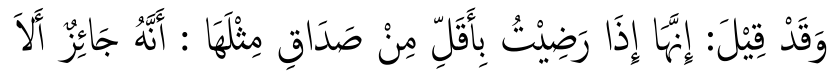

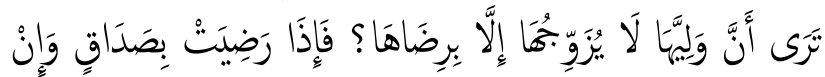

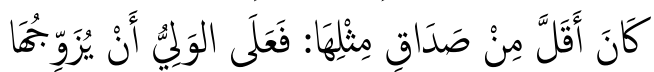

Artinya : "Ada yang berpendapat, jika pengantin setuju dengan mahar di bawah mahar mitsl, itu boleh. Tidakkah anda perhatikan bahwa wali tidak boleh menikahkan si wanita kecuali dengan kerelaan si wanita?]ika si wanita ridha dengan nilai mahar, meskipun kurang dari mahar mitsl, maka wali harus menikahkannya."

Setelah melihat pendapat responden pada tabel 4 tentang nominal uang jujuran, 6 (enam) responden berbeda pendapat, ada yang mengatakan Jujuran itu tidak ada nominalnya, uang Rp.20.000, terserah kedua belah pihak, tergantung ekonomi masyarakat, tergantung persetujuan perempuan, hasil musyawarah.

Sedangkan hemat penulis bahwa kalau Jujuran itu bukan termasuk dalam mahar, karena dalam Hukum Islam mahar itu bukan hanya nominal semata melainkan bisa dengan benda atau sejenisnya bahkan hafalan ayat suci Alqur'an pun bisa dijadikan sebagai mahar. Menurut hadits yang diriwayatkan oleh Bukhori dan Muslim ini dijelaskan bahwa dibolehkannya maskawin atau mahar dengan hafalan ayat-ayat suci Al-qur'an. Karena pendapat para responden hanya menyangkutkan Jujuran itu dengan materi saja berupa uang.Maka Jujuran bukan termasuk dari mahar sesuai anjuran dalam hukum Islam. Setelah melihat pendapat reponden pada tabel 5 tentang dampak uang Jujuran yang tidak diberikan, 3 (tiga) responden menyatakan sama yaitu berhutang terlebih dahulu setelah itu bayar kemudian. 2 (dua) responden menyatakan sama yaitu pernikahannya tidak jadi dilaksanakan dan akan batal, I (satu) responden menyatakan tidak jadi nikahnya dan bisa dituntut.

Oleh sebab itu merupakan suatu pemberatan jika memang hanya karena uang jujuran yang tidak bisa dipenuhi, pernikahannya dibatalkan. Dalam hukum Islam nikah itu tidak boleh dibuat susah atau diberatkan apalagi jika kedua calon sudah suka sama suka. Abu Dawud meriwayatkan dari 'Uqbah bin 'Amir Radhiyallahu anhu, ia mengatakan: "Rasulullah SAW bersabda:

$$
\text { خَيْرُ النِّكَاح اََُْْسرُهُ. }
$$

\section{Artinya :"Sebaik-baik pernikahan ialah yang} paling mudah." 
Hadits ini HR. Abu Dawud (no. 2II7) kitab an-Nikaah, al-Hakim (II//82), ia menshahih-kannya dan menilainya sesuai syarat Syaikhan (al-Bukhari-Muslim), dan Syaikh alAlbani menilainya sesuai syarat Muslim. Lihat alIrwaa' (VI/345). Hadits ini yang mendasari Penulis dalam menganalis jawaban responden tersebut.Selain hadits tersebut dalam Pasal 31 Kompilasi Hukum Islam disebutkan bahwa "Penentuan mahar berdasarkan atas kesederhanaan dan kemudahan yang dianjurkan oleh ajaran Islam." Setelah melihat pendapat responden pada tabel 6 tentang calon pengantin laki-laki yang tidak sanggup membayar uang Jujuran.Dari 6 (enam) responsen.yang pendapatnya sama yaitu 2 (dua) responden yang mengatakan bisa dengan jalan musyawarah, sedangkan 4 (empat) responden lainnya berbeda pendapat. Ada yang menyatakan bisa dengan diangsur, pendapat berikutnya jika tidak sanggup maka dibatalkan pernikahannya, ada yang menyatakan bisa kawin lari, dan ada juga yang mengatakan bisa dilakukan tawar menawar berapa kesepakatannya yang disanggupi.

Berdasarkan pengalaman gagalnya pernikahan karena jujuran di luar kesanggupan laki-laki yang akan menikah dengan perempuan yang dilamarnya, maka hal tersebut bertentangan dalam hukum Islam karena itu merupakan pemberatan kemampuan bagi calon pengantin laki-laki, sedangkan menurut hukum Islam dalam pernikahan itu tidak boleh diberatkan alasannya sesuai dengan yang telah Penulis paparkan sebelumnya di atas. Hukum Islam menghendaki pernikahan itu mudah dilaksanakan baik dari pelaksanaannya maupun dari maharnya, sesuai dengan sabda Rasulalloh SAW :

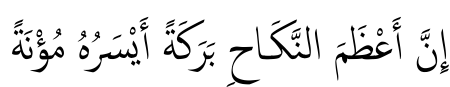

Artinya : "Pernikahan yang paling besar keberkahannya ialah yang paling mudah maharnya."

Hadits di atas menjelaskan bahwa keberkahan dari sebuah pernikahan adalah ketika maharnya mudah dan tidak memberatkan bagi pihak laki-laki.Rasulullah SAW mengajarkan kepada kita kemudahan dalam mahar agar kita meneladaninya.Imam Abu Dawud meriwayatkan dari 'Abdullah bin 'Abbas Radhiyallahu anhuma, ia mengatakan, "Ketika "Ali bin Abi Thalib menikah dengan Fathimah, maka Rasulullah SAW bersabda, "Berikanlah sesuatu kepada Fatimah (sebagai mahar)." Ali menjawab "Aku tidak mempunyai sesuatu." Beliau bertsabda, "Di mana baju besimu ?" Lalu ia memberikan baju besinya kepada Fathimah, kemudian menggaulinya.

Setelah melihat pendapat responden pada tabel 7 tentang pandangan hukum Islam mengenai cara yang dilakukan kedua belah pihak dalam menyelesaikan problematika penentuan Jujuran. Untuk 5 (Lima) responden diantaranya sama mengemukakan pendapatnya yaitu harus ada mufakat dari kedua belah pihak, sedangkan I (satu) diantaranya berbeda pendapat, yaitu jika mahar itu wajib hukumnya dan Jujuran itu sesuai kemampuan pihak laki-laki. Dari tabel tersebut, bahwa agama Islam sebagai agama yang penuh rahmat menerima adat dan budaya selama tidak bertentangan dengan Syari'at Islam dan kebiasaan tersebut telah menjadi suatu ketentuan yang harus dilaksanakan dan dianggap sebagai aturan atau norma yang harus ditaati, maka adat tersebut dapat dijadikan pijakan sebagai suatu hukum Islam yang mengakui keefektifan adat istiadat dalam interpretasi hukum. Sebagaimana kaidah fiqhiyah:

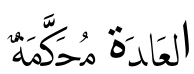

Artinya: "Adat kebiasaan dapat ditetapkan sebagai hukum."

Dengan adanya tradisi tentang Jujuran yang berada di Kecamatan Pahandut Kota Palangka Raya, jika itu memang tidak bertentangan, maka sesuai kaidah di atas hal tersebut diperbolehkan. Apabila dihubungkan dengan macam-macam mata pencaharian penduduk di Kecamatan Pahandut yang apabila dari tingkat ekonominya dinilai cukup memadai untuk memberikan Jujuran maka hal tersebut bukanlah sesuatu yang memberatkan karena Jujuran yang diminta pihak perempuan dianggap cukup terjangkau, kalaupun itu menjadi hutang wajib dibayar oleh pihak laki-laki dengan adanya suatu perjanjian perkawinan sebelum akad nikah dilaksanakan Hukum Islam memberikan peluang tersebut kepada calon mempelai laki-laki (suami) dan calon mempelai perempuan (istri) untuk mengadakan perjanjian perkawinan berkaitan dengan harta benda mereka sebelum 
dilaksanakan akad nikah apabila memang tradisi Jujuran itu dianggap sebagai pemberian harta awal dari seorang laki-laki kepada seorang perempuan yang akan dinikahinya.

sedangkan Hukum Islam mengakomodir tradisi Jujuran tersebut sebagaimana tercantum dalam Kompilasi Hukum Islam Pasal 30 yang berbunyi: "Calon mempelai pria wajib membayar mahar kepada calon mempelai wanita yang jumlah, bentuk dan jenisnya disepakati oleh kedua belah pihak," dan Pasal 45 yang berbunyi: Kedua calon mempelai dapat mengadakan perjanjian perkawinan dalam bentuk:

I. Taklik talak dan

2. Perjanjian lain yang tidak bertentangan dengan hukum Islam,"

\section{Penutup}

Peminangan menuju jenjang pernkahan salah satu yang dibicarakan adalah adanya Mahar atau Jujuran sudah kewajiban berdasarkan kesepakatan dari kedua belah pihak, berarti diterimanya proses lamaran dan pernikahan dapat dilanjutkan ke akad nikah dan walimah. Akan tetapi Jujuran tidak berhasil disepakati sering terjadi batalnya pernikahan, yang membuat si Lelaki dan si Perempuan sudah terlanjur saling menyukai, karena terkendala tidak disepakatinya jumlah Mahar/Jujuran dikhawatirkan mengakibatkan perbuatan Negatif/dilarang Agama dilakukan.

Sedangkan dalam pandangan Hukum Islam terhadap tradisi Jujuran pada masyarakat suku Banjar di Kecamatan Pahandut Kota Palangka Raya adalah berdasarkan kaidah Hukum Islam yang menyatakan bahwa adat kebiasaan dapat ditetapkan sebagai hukum Maksudnya ialah walaupum Jujuran tidak termasuk dalam rukun dan syarat pernikahan namun keberadaan tradisi Jujuran tersebut dapat mempengaruhi sah atau tidak sahnya suatu pernikahan, kalau identik dengan mahar maka tanpa Jujuran batal pernikahan tersebut dan kalau tidak identik dengan mahar akan berlanjut pernikahan tersebut.

\section{A. Al-Qur'an}

Alfatih, Kitab Al-Qur'an Al-Fatih dengan alat peraga tajwid kode arab, PT Insan Pustaka, 20I2,

Binjai, Abdul Halim Hasan, Tafsir Al-Ahkam. Jakarta, Kencana, 2006.

B. Hadits

Ash-Shan'ani, Muhammad bin Ismail AlAmir, Subul As-Salam Syarah Bulughul Maram. diterjemahkan oleh Muhammad Isnan dkk, dengan judul Subulus Salam - Syarah Bulughul maram.jakarta, Darus Sunnah press jilid ke 2 cet. 9, 2013.

Fu'ad Abdul Baqi, Muhammad, Al-lu'lu Wal Marjan, diterjemahkan oleh Taufik Munir, dengan judul Al-lu'lu Wal Marjan, Jakarta: Pustaka Al-Kautsar, 2011

Hajar Al-Asqolani, Ibnu, Bulughul Maram min Adillatil Ahkam, diterjemahkan oleh Harun Zen dan Mutaqin , dengan judul Bulughul Maram, Jakarta: JABAL, 20I I

Sabiq Sayyid Fiqhus Sunnah.diterjemahkan olehMoh. Abidun dkk,Fiqih Sunnahjilid 3.Jakarta,Pena Pundi Aksara, 20II.

\section{Buku}

Abdullah, M. Amin, dkk., Metodologi Penelitian Agama: Pendekatan Multi disipliner, Yogyakarta: Kurnia Kalam Semesta, 2006.

Abdurrahman, Kompilasi Hukum Islam.Jakarta, Akademika Pressindo, 2015.

Abidin, Slamet dan H. Aminudin, Fikih Munakahat I, Bandung: CV. PUSTAKA SETIA, 1999.

Ali, Mohammad Daud, Hukum Islam dan Peradilan Agama. Jakarta, PT Raja Grafindo, 2002.

Arikunto, Sursimi, Manajemen Penelitian, Jakarta, PT Rineka Cipta, 2003. 
Arifin, Jaenal, Kamus Ushul Fikih dalam Dua Bingkai ljtihad, Jakarta, Kencana Prenada Media Group, 2012

Ariyadi, Ariyadi. "Metodologi Istinbath Hukum Prof. Dr. Wahbah Az Zuhaili." Jurnal Hadratul Madaniyah 4.I (2017): 32-39.

Asy-syuri, Mazdi bin Manshur bin Sayyid, Tuhfah al-Arusain, diterjemahkan olehAhmad Syaikhu, dengan judul Mahkota Pengantin.Jakarta,2009.

Ash-Syafa, Burhan, Metode Penelitian Hukum, Jakarta: PT. Rineka Cipta, 1998

Azam, Muhammad Aziz Abdul dan Hawwas Sayyed Wahhab Abdul, Al usrotu wa ahkamuha fil tashrii I'l islami. diterjemahkan oleh Abdul Majid Khon, Figh Munakahat. Jakarta, AMZAH, 2015

Baqry, Sidi Nazar, Kunci Keutuhan Rumah Tangga. Jakarta, Pedoman IImu Jaya, cet. Ke-l, 1993.

Daud, Alfani, Islam dan Masyarakat Banjar, Jakarta: Raja Grapindo Persada, 1997.

Departemen Agama RI, Undang-Undang Nomor I Tahun 1974 Tentang Perkawinan Dan Peraturan pemerintah Nomor 9 Tahun 1975 serta Kompilasi Hukum Islam DI Indonesia, Jakarta: Departemen RI, 2004

Djazuli, A. dan Nurul Aen, Ushul Figh Metodologi Hukum Islam, Jakarta: Raja Grafindo Persada, 2000.

Djazuli, A., Kaidah-Kaidah Hukum Islam Dalam Menyelesaikan MasalahMasalah yang Praktis, Jakarta: Raja Grafindo Persada, 2000.

Dimyati, Mursimah, Perkawinan Adat Banjar Dan Tata Rias Pengantin Banjar Dari Masa Ke Masa Banjarbaru: PT. Grafika Wangi Kalimantan, 2005.

Departemen Agama RI, Undang-undang Nomor I Tahun 1974 Tentang Perkawinan Dan Peraturan Pemerintah Nomor 9 Tahun 1975 Serta Kompilasi Hukum Islam Di Indonesia, Jakarta: Departemen Agama RI, 2004.

Jumantoro, Totok dan Samsul Munir Amin, Kamus Ilmu Ushul Fikih, t.tp: AMZAH, 2005
Hafsh Usamah Bin kamal Bin 'Abdir Razzaq, Abu, Isyratun Nissa' minal alif ilal ya, diterjemahkan oleh Ahmad Syaikhu, dengan judul Panduan Nikah Lengkap (A sampai Z), Bogor: PUSTAKA IBNU KATSIR, 2005

Khairul Uman, dkk. Ushul Fikih I, Bandung: CV. Pustaka setia, 2002.

Khalaf, Abdul Wahhab, Kaidah-Kaidah Hukum Islam (IImu Ushul Figh), Jakarta: Raja Indo persada, 2002.

Mahfudz, Gusti, Pola Perkawinan Adat Banjar Di Kalimantan Selatan, Yogyakarta: Lembaga Kependudukan UGM, t.t., 2000.

Moleong, Lexy, Metode penelitian kualitatif, Bandung: PT Remaja Rosada Karya, 1996.

Muhammad, Syaikh Kamil, 'uwaidah, Fiqih Wanita, Jakarta: Pustaka al-kautsar, 1998.

Nasution S, Metode Penelitian Kualitatif, Bandung: Tarsito, 1988

Syaik Ahmad Zad, Sahahih Figh As-Sunnah Li Annisa, Ditertejamhkan oleh Masturi Ilham dan Nurhadi, dengan judul Fikih Sunnah Wanita Panduan lengkap Menjadi muslimah shalehah, Jakarta Timur, Pustaka-Alkautsar 2008.

Syaikh Muhammad bin Shaih al-'Utsaimin, Figh Al-Maratul Muslimah.diterjemahkan oleh Faisal Saleh dan Yusuf Hamdani, Shahih Fiqih Wanita. Jakarta, Akbar Media, 2014.

Syuaisyi',Syaikh Hafizh Ali, Kado Pernikahan.Jakarta, Pustaka AlKautsar, 2005.

Tihami, H. M.A, dan Sohari Sahrani, Fikih Munakahat Kajian Fikih Nikah Lengkap, Jakarta: PT. Raja Grafindo Persada, 2010

Tim Penyusun Kamus Pusat Pembinaan dan pengembangan Bahasa, Kamus Besar Bahasa Indonesia, Jakarta: Balai Pustaka, 2005

Usman, Muchlis, Kidah-kaidah Ushuliyah dan Fiqhiyah, Jakarta: PT. Raja Grafindo Persada, 1999.

Usman, Muhlish, Kaidah-Kaidah Ushuliyah dan Fighiyah Pedoman Dasar Dalam 
Pedoman Hukum Islam, Jakarta: PT. Raja Grafindo Persada, 1996.

Waluyo, Bambang, Penelitian Hukum Dalam Praktek, Jakarta: Sinar Grafika, 199I. 'uwaidah, Syaikh Kamil Muhammad , Fiqih Wanita, Jakarta, Pustaka al-kautsar, 1998

\section{Ensiklopedi}

Ensiklopedi Islam, jilid I, Jakarta: PT. Ichtiar Baru Van Hoere, 1999

\section{E. Internet}

http://bjn.Wikipedia.org/wiki/jujuran,

(Diunduh pada tanggal 27 November 2016)

http://galericerpen-

flp.blogspot.com/201 I/02/jujuran.ht $\mathrm{ml}$, (Diunduh pada tanggal 27 November 2016)

Khairilmuslim.wordpress.com/20I I/03/I5/t radisi-jujuran/. (Diunduh pada tanggal 28 November 2016) 